\title{
Cystatin C Based Evaluation of Renal Function in Hypertensive Patients in Ubth, Benin City
}

\author{
Alaje Abiodun $\mathrm{K}^{1}$, Idogun Sylvester $\mathrm{E}^{2}$, Idemudia Joseph $\mathrm{O}^{3}$. \\ ${ }^{1,2,3}$ Department Of Chemical Pathology,University Of Benin Teaching Hospital,Benin City.
}

\begin{abstract}
Background: Hypertension is a recognized cause of chronic kidney disease. Hypertension in blacks is most important because it is volume dependent and its ensuing renal complication. The widely accepted marker to assess renal function is creatinine and its estimated glomerular filtration rate. However, this is limited in assessing early renal impairment. This necessitate a need to evaluate other renal markers such as cystatin $C$.

Objective: To measure and compare serum cystatin $C$ and creatinine for early renal impairment among hypertensive patients on treatment.

Methodology: A total of 48 hypertensive patients attending cardiology clinic for follow up were recruited in this study. Serum specimen were collected and assayed for creatinine and cystatin C. estimated glomerular filtration (eGFR) rate was calculated for the analytes. The two eGFR were compared in assessing renal function.

Results: The BMI, Blood pressure and Abdominal circumference of the subjects were significantly higher than the controls $\left(31.5 \pm 7.5 \mathrm{~kg} / \mathrm{m}^{2}, 144 / 82 \mathrm{mmHg}\right.$ and $102.3 \mathrm{~cm} v \mathrm{vs} 26.1 \pm 4.3 \mathrm{~kg} / \mathrm{m}^{2}, 116 / 80 \mathrm{mmHg}$ and $\left.93 \mathrm{~cm}\right)$ respectively Table 1. The hypertensives had a significantly higher serum levels of creatinine and cystatin $C$ when compared with the controls $(105 \mu \mathrm{mol} / \mathrm{L}$ vs $88 \mu \mathrm{mol} / \mathrm{L}$ and $2.9 \mathrm{mg} / \mathrm{L}$ vs $1.1 \mathrm{mg} / \mathrm{L})$ respectively Table 2 . Calculated estimated GFR for both serum creatinine and cystatin C were significantly lower among the subjects $\left(89.1 \mathrm{ml} / \mathrm{min} / 1.73 \mathrm{~m}^{2}\right.$ vs $110 \mathrm{ml} / \mathrm{min} / 1.73 \mathrm{~m}^{2}$ and $67.7 \mathrm{ml} / \mathrm{min} / 1.73 \mathrm{~m}^{2}$ vs $118 \mathrm{ml} / \mathrm{min} / 1.73 \mathrm{~m}^{2}$ ). Estimated GFR based on cystatin $\mathrm{C}$ was significantly lower than eGFR-Cr among the subjects $\left(67.7 \mathrm{ml} / \mathrm{min} / 1.73 \mathrm{~m}^{2}\right.$ vs $\left.89.1 \mathrm{ml} / \mathrm{min} / 1.73 \mathrm{~m}^{2}\right)$. There was a significant correlation between BMI and eGFR-Cr, abdominal circumference also had a significant correlation with fasting plasma glucose among the subjects and controls.
\end{abstract}

Conclusion: serum levels of cystatin C appears to be a better predictor of GFR among hypertensive patients.

Keywords: Hypertension, Creatinine, Cystatin C, eGFR..

\section{Introduction}

Hypertension is defined as a systolic blood pressure of $140 \mathrm{mmHg}$ or more and a diastolic blood pressure of $90 \mathrm{mmHg}$ or more. The prevalence of hypertension in Nigeria is high and many patients are urban dwellers ${ }^{1}$. Hypertension has been found to be high among those 20years and above with a slight male preponderance ${ }^{1}$.This represents the work force of any community.

Hypertension in blacks is a notable cause of kidney disease and usually progress to end stage renal failure due to late presentation ${ }^{2}$. Lack of proper medical treatment of hypertension can also result in complications like stroke, visual impairment and renal disease ${ }^{3}$.

Chronic kidney disease is a known complication of hypertension especially when the blood pressure is uncontrolled ${ }^{3}$.

In blacks, hypertension runs a more aggressive course and many hypertensive patients present with hypertensive nephroslecrosis ${ }^{4}$. The prevalence of hypertensive nephrosclerosis in Nigeria was reported to be $26.1 \%^{2}$. A study in Maiduguri, Nigeria reported a prevalence as high as $45.5 \%$ of impaired kidney function among hospitalized hypertensive patients ${ }^{5}$. At presentation, many patients are already in the late stages of $\mathrm{CKD}^{2}$. The late presentation may be due to asymptomatic nature of hypertension and insensitivity of endogenous creatinine used in assessing renal function.

The widely accepted endogenous renal marker is serum creatinine and its estimated GFR ${ }^{6}$. However, its use is limited because it is insensitive to early renal impairment, and it is affected by spectral interferences. Serum creatinine is also affected by age and gender ${ }^{7}$. The limited use of serum creatinine necessitated evaluation of other renal markers like cystatin C. Many studies done on the relevance of cystatin $\mathrm{C}$ to assess renal function reported that cystatin $\mathrm{C}$ is important for early detection of renal impairment. Cystatin $\mathrm{C}$ is a low molecular weight protein which makes it to be freely filtered by the kidneys, almost completely (99\%) reabsorbed and catabolized by the renal tubules ${ }^{8-9}$. However, there was a report that cystatin $\mathrm{C}$ is secreted by the tubules in hypertensive patients ${ }^{10-11}$. Unlike creatinine, serum cystatin $C$ is not affected by age, sex, there is no known extra-renal route of its elimination and its serum concentration is not influenced by spectral interferences ${ }^{12-13}$. The high burden of hypertension and renal disease in this group patients calls for a need to evaluate other 
potential renal markers for early detection and management. This will slow down the progression of renal disease and reduce the burden of end stage kidney disease.

\section{Methodology}

This study was carried out between March and July 2014 at the University of Benin Teaching Hospital (UBTH) Benin City. It is a tertiary hospital and has about 600 bed capacity. It serves as a major referral Centre to neighboring states. The subjects recruited for this study were hypertensive patients attending cardiology clinic for more than a year.

Hypertensive patients with proteinuria of $2+$ and above as well as those with co-morbid diabetes mellitus were excluded from this study.

The blood pressure of the subjects were taken using mercury sphygmomanometer. Height and weight were measured using a Stadiometer. Body mass index of all subjects was calculated from the formula: BMI = Weight $(\mathrm{Kg}) /$ height $\left(\mathrm{m}^{2}\right)$.

Five milliliter $(5 \mathrm{ml})$ of blood was collected from each patients into a plain tube and the blood was allowed to clot. The clotted blood was centrifuged at $1500 \mathrm{~g}$ and serum harvested into a clean specimen bottle. The serum specimens were stored at $-20^{\circ} \mathrm{C}$ for two months until enough specimen pooled for analysis.

Serum creatinine was assayed using kinetic Jaffe method while serum cystatin $\mathrm{C}$ assayed using immunoturbidimetric method. Two values of estimated GFR were computed, eGFR-Cr using cockroft-Gault formula and eGFR-cyst using simple cystatin $\mathrm{C}$ formula.

eGFR- $\mathrm{Cr}=(140-$ Age in years) $\mathrm{x}$ Weight $(\mathrm{kg}) / 72 \times$ Creatinine $(\mathrm{mg} / \mathrm{dL}) \times 0.85$ (if Female).

eGFR- Cyst $=100 /$ cystatin C mg/L.

Ethical clearance for this study was obtained from the ethical committee of the UBTH. All participant gave an informed consent for this study. Data was analyzed using the statistical package for social science(SPSS) version 16. Numerical variables were expressed as mean and standard deviations. Means were compared in both groups using Student's t test. Pearson's correlation test was used for correlation study.The Pvalue $\leq 0.05$ was taken as the cut off level for significance.

\section{Results}

The subjects had a mean BMI, abdominal circumference, systolic and diastolic blood pressure that were significantly higher than the controls. The subjects were obese with a mean BMI of $31.5 \pm 7.5 \mathrm{~kg} / \mathrm{m}^{2}$ while controls were slightly overweight (BMI of $26.1 \pm 4.3 \mathrm{~kg} / \mathrm{m}^{2}$ ). Table 1 . The subjects had a significantly higher abdominal circumference that the controls $(102.3 \pm 15.3 \mathrm{~cm}$ and $93.0 \pm 9.5 \mathrm{~cm})$. The systolic and diastolic blood pressure were also significantly higher among the subjects $(144.2 \pm 0.8 \mathrm{mmHg}$ vs $116.4 \pm 9.9 \mathrm{mmHg}$ and 87.8 $\pm 16.7 \mathrm{mmHg}$ vs $79.7 \pm 7.3 \mathrm{mmHg}$ ) respectively. Table 2 .

The subject's serum creatinine and cystatin $C$ were significantly higher than the controls $(105 \pm 30 \mu \mathrm{mol}$ vs $88 \pm 30 \mu \mathrm{mol}$ and $3.1 \pm 2.0 \mathrm{mg} / \mathrm{L}$ vs $1.1 \pm 0.9 \mathrm{mg} / \mathrm{L}$ respectively) Table 2 .

The subjects had a significantly lower eGFR-Cr and eGFR-Cystatin than the controls $\left(89.1 \pm 28.9 \mathrm{ml} / \mathrm{min} / 1.73 \mathrm{~m}^{2}\right.$ vs $\left.67.7 \pm 10.5 \mathrm{ml} / \mathrm{min} / 1.73 \mathrm{~m}^{2}\right)$ and $\left(110 \pm 43 \mathrm{ml} / \mathrm{min} / 1.73 \mathrm{~m}^{2}\right.$ vs $\left.118 \pm 44 \mathrm{ml} / \mathrm{min} / 1,73 \mathrm{~m}^{2}\right)$ respectively Table 2 . However, the eGFR-cystatin was significantly lower than eGFR-Creatinine only among the subjects $\left(67.7 \pm 51.6 \mathrm{ml} / \mathrm{min} / 1.73 \mathrm{~m}^{2}\right.$ vs $\left.89.12 \pm 28.9 \mathrm{ml} / \mathrm{min} / 1.73 \mathrm{~m}^{2}\right)$ Table 3 .

The fasting plasma glucose correlated positively with BMI and abdominal circumference among the subjects $(r=433, p=.035 ; r=451, p=.027)$ and with only abdominal circumference among the controls $(r=0.384$, $\mathrm{p}=.027)$. These correlations are significant. Tables 5 and 6 .

There was a positive correlation between eGFR-Cr and BMI. This correlation was observed in the subjects and controls $(\mathrm{r}=.408, \mathrm{p}=.048 ; \mathrm{r}=.378, \mathrm{p}=.023)$ respectively. However, a significant positive correlation was observed between eGFR-Cr and abdominal circumference only for the subjects $(\mathrm{r}=.486$, $\mathrm{p}=.016)$ Table 5 and 6.

Serum Cystatin C positively correlated with systolic blood pressure among the subjects $(r=0.472, p=$ $0.02)$ and negatively correlated with diastolic blood pressure among the controls $(\mathrm{r}=-0.352, \mathrm{p}=0.035)$. Estimated GFR-cystatin had a positive correlation with diastolic blood pressure among the controls $(r=.379, \mathrm{p}=.023)$. Table 5 and 6.

Table 1: Demographc Parameters Of Subjects And Controls

\begin{tabular}{|l|l|l|l|}
\hline & SUBJECTS $\mathrm{n}=48$ & CONTROLS $\mathrm{n}=36$ & P value \\
\hline AGE (years) & $57 \pm 11.9$ & $54 \pm 6.6$ & 0.35 \\
\hline FEMALES & $28(58.3 \%)$ & $18(50 \%)$ & \\
\hline MALES & $20(41.7 \%)$ & $18(50 \%)$ & 0.846 \\
\hline BMI & $31.5 \pm 7.5$ & $26.1 \pm 4.3$ & 0.023 \\
\hline
\end{tabular}


Table 2: Physical Examination And Biochemical Parameters Between Thesubjects And Controls

\begin{tabular}{|l|l|l|l|}
\hline & SUBJECTS $\mathrm{n}=48$ & CONTROLS $\mathrm{n}=32$ & P VALUE \\
\hline SYSTOLIC BP(mmHg) & $144.2 \pm 0.8$ & $116.4 \pm 9.9$ & $<0.05$ \\
\hline DIASTOLIC BP(mmHg) & $87.8 \pm 16.7$ & $79.7 \pm 7.3$ & $<0.05$ \\
\hline ABDOMINAL CIRCUMFERENCE $(\mathrm{CM})$ & $102.3 \pm 15.3$ & $93.0 \pm 9.5$ & 0.002 \\
\hline FPG $(\mathrm{mmol} / \mathrm{L})$ & $5.3 \pm 1.4$ & $5.2 \pm 1.0$ & 0.4 \\
\hline SERUM CREATININE $(\mu \mathrm{mol} / \mathrm{L})$ & $105 \pm 30$ & $88 \pm 30$ & 0.009 \\
\hline CYSTATIN C $(\mathrm{mg} / \mathrm{L})$ & $2.9 \pm 2.3$ & $1.1 \pm 0.9$ & $<.05$ \\
\hline eGFR-Cr & $89.1 \pm 28.9$ & $110 \pm 43$ & 0.02 \\
\hline eGFR-Cystatin & $67.7 \pm 10.5$ & $118 \pm 44$ & $<0.05$ \\
\hline
\end{tabular}

Table 3: Physical Examination Between Male And Female Hypertensives

\begin{tabular}{|l|l|l|l|}
\hline & $\begin{array}{l}\text { MALES } \\
\mathrm{N}=20\end{array}$ & $\begin{array}{l}\text { FEMALES } \\
\mathrm{N}=28\end{array}$ & P VALUE \\
\hline BMI $\left(\mathrm{kg} / \mathrm{m}^{2}\right)$ & $28.6 \pm 3.2$ & $33.5 \pm 9$ & 0.011 \\
\hline SYSTOLIC BP(mmHg) & $143.0 \pm 24.0$ & $145.0 \pm 19.1$ & 0.236 \\
\hline DIASTOLIC BP(mmHg) & $92.6 \pm 17.8$ & $84.3 \pm 15.5$ & 0.384 \\
\hline ABDOMINAL CIRCUMFERENCE (CM) & $97.5 \pm 9.8$ & $105.7 \pm 17.9$ & 0.108 \\
\hline FPG $(\mathrm{mmol} / \mathrm{L})$ & $101.6 \pm 29.1$ & $89.7 \pm 22.9$ & 0.822 \\
\hline SERUM CREATININE (UMOL/L) & $1.2 \pm 0.3$ & $0.9 \pm 0.2$ & 0.788 \\
\hline CYSTATIN C $(\mathrm{mg} / \mathrm{L})$ & $3.1 \pm 2.0$ & $2.7 \pm 2.5$ & 0.700 \\
\hline eGFR-Cr $(\mathrm{ml} / \mathrm{min})$ & $82.1 \pm 26.9$ & $94.2 \pm 30.2$ & 0.416 \\
\hline eGFR-Cystatin $(\mathrm{ml} / \mathrm{min})$ & $57.9 \pm 16.3$ & $74.6 \pm 14$ & 0.618 \\
\hline
\end{tabular}

Table 4: Comparism Of Gfr Between Egfr-Cr And Egfr-Cytatin C

\begin{tabular}{|l|l|l|l|}
\hline & eGFR-Cr & eGFR-Cystatin C & P Value \\
\hline SUBJECTS & $89.12 \pm 28.9$ & $67.7 \pm 51.6$ & 0.048 \\
\hline CONTROLS & $110.2 \pm 43.0$ & $112.5 \pm 46.4$ & 0.387 \\
\hline
\end{tabular}

Table 5: Correlation Of Egfr With Measured Parameters Among Subjects

\begin{tabular}{|l|l|l|l|l|l|l|}
\hline & & FPG & CREATININE & CYSTATIN & Egfr-CR & $\begin{array}{l}\text { EGFR- } \\
\text { CYSTTIN }\end{array}$ \\
\hline SYSTOLIC B.P & R VALUE & .111 & .048 & $.472^{*}$ & .019 & -.259 \\
\hline & P VALUE & .605 & .823 & .020 & .930 & .221 \\
\hline & $\mathrm{N}$ & 48 & 48 & 48 & 48 & 48 \\
\hline DIATOLIC B.P & R VALUE & .019 & .204 & .127 & .084 & -.249 \\
\hline & P VALUE & .929 & .340 & .553 & .697 & .240 \\
\hline & $\mathrm{N}$ & 48 & 48 & 48 & 48 & 48 \\
\hline FPG & R VALUE & 1 & .308 & -.007 & -.039 & .012 \\
\hline & P VALUE & & .143 & .975 & .853 & .956 \\
\hline & $\mathrm{N}$ & 48 & 48 & 48 & 48 & 48 \\
\hline BMI & R VALUE & $.433^{*}$ & .103 & .087 & $.408^{*}$ & .002 \\
\hline & P VALUE & .035 & .632 & .686 & .048 & .994 \\
\hline & $\mathrm{N}$ & 48 & 48 & 48 & 48 & 48 \\
\hline ABDOMINAL & R VALUE & $.451^{*}$ & -.003 & -.045 & $.486^{*}$ & .171 \\
\hline & P VALUE & .027 & .988 & .833 & .016 & .423 \\
\hline & $\mathrm{N}$ & 48 & 48 & 48 & 48 & 48 \\
\hline & & 48 & & & \\
\hline
\end{tabular}

*Correlation is significant at 0.05 (two tail)

**Correlation is significant at 0.01 (two tail)

Table 6: Correlation Of Biochemical Parameters Among Controls

\begin{tabular}{|l|l|l|l|l|l|l|}
\hline & & FPG & CREATININE & CYSTATIN & Egfr-CR & $\begin{array}{l}\text { EGFR- } \\
\text { CYSTTIN }\end{array}$ \\
\hline SYSTOLIC B.P & R VALUE & .180 & .108 & -.270 & .067 & .176 \\
\hline & P VALUE & .293 & .530 & .112 & .698 & .304 \\
\hline & $\mathrm{N}$ & 36 & 36 & 36 & 36 & 36 \\
\hline DIATOLIC B.P & R VALUE & .172 & .083 & $-.352^{*}$ & .102 & $.379^{*}$ \\
\hline & P VALUE & .315 & .629 & .035 & .555 & .023 \\
\hline & $\mathrm{N}$ & 36 & 36 & 36 & 36 & 36 \\
\hline FPG & R VALUE & 1 & .144 & .112 & .069 & -.003 \\
\hline & P VALUE & & .401 & .514 & .688 & .986 \\
\hline & $\mathrm{N}$ & 36 & 36 & 36 & 36 & 36 \\
\hline & R VALUE & .313 & -.070 & -.132 & $.378^{*}$ & .089 \\
\hline & P VALUE & .063 & .685 & .442 & .023 & .604 \\
\hline BBI & $\mathrm{N}$ & 36 & 36 & 36 & 36 & 36 \\
\hline & R VALUE & $.384^{*}$ & .137 & -.062 & .112 & .054 \\
\hline & P VALUE & .021 & .425 & .718 & .514 & .752 \\
\hline
\end{tabular}


*Correlation is significant at 0.05 (two tail)

** Correlation is significant at 0.01 (two tail)

\section{Disussion}

The subjects recruited for this study were hypertensive patients with follow up clinic attendance for at least one year. These patients had been on antihypertensive drugs. However, the blood pressure readings of these patients suggest they are not in good control of the B.P. This observation might be due to factors like poor drug compliance, suboptimal dosing of drugs or purchase of substandard drugs. The WHO recommendation for optimal blood pressure for follow up of hypertensive patients, states that the values should be $130 / 90 \mathrm{mmHg}$ or below. Uncontrolled blood pressure is a known risk factor for the development of $\mathrm{CKD}^{3}$. The results of serum creatinine and cystatin $\mathrm{C}$ with the low estimated GFR obtained from this study revealed that many of these patients have developed chronic kidney disease. Ulasi et al had earlier reported that inadequate treatment or control of blood pressure contribute to the development of $\mathrm{CKD}^{14}$.

This study found that the subjects were obesed and this includes abdominal obesity. Obesity is a recognized cause of chronic kidney disease ${ }^{2}$. Abdominal obesity is associated with abnormal lipid metabolism and is a major risk factor for cardiovascular events ${ }^{15-16}$. Decline in renal function may be worsened in hypertension when there is co-existing disease such as obesity because obesity alone is an identified cause of $\mathrm{CKD}^{2}$.

This study observed that serum creatinine and cystatin $\mathrm{C}$ were elevated among the hypertensive patients. This observation might be due to reduce renal clearance of these analytes secondary to reduced renal perfusion. There was reduction in estimated glomerular filtration rate calculated using serum creatinine and cystatin $\mathrm{C}$. This supports the fact that there is a reduced renal function in hypertension. However, the eGFRCyst $\mathrm{C}$ was found to be lower than eGFR-Cr. This suggests that serum cystatin $\mathrm{C}$ has a better discriminatory ability than serum creatinine. Newman in his study reported that serum cystatin $\mathrm{C}$ increased sooner than serum creatinine with a decline GFR ${ }^{17}$.

It was observed that serum cystatin $\mathrm{C}$ increased as systolic blood pressure increased among the subjects while serum cystatin $\mathrm{C}$ decreased with increased diastolic blood pressure among the controls. This is similar to earlier reports that the systolic blood pressure poses a greater risk for cardiovascular events and kidney disease progression ${ }^{18}$.

The influence of body mass index on estimated GFR using serum creatinine was observed for the subjects and controls. This supports earlier reports that serum creatinine is influenced by weight, this limits the use of creatinine equation for estimating GFR.6Ref On the contrary, serum cystatin C and eGFR were not influenced by factors such as BMI or abdominal circumference. Front et al reported that cystatin $\mathrm{C}$ is not affected by extrarenal factors ${ }^{12}$.

This study observed that obesity was associated with increase blood pressure, fasting plasma glucose and elevated eGFR-Cr. Conversely, blood pressure influences the serum concentration of cystatin C and eGFRcysttain. Therefore, blood pressure should be considered when reporting cystatin $\mathrm{C}$ result. Serum Cystatin $\mathrm{C}$ is a better alternative marker for eGFR especially among hypertensive patients with normal serum creatinine especially for patients with uncontrolled blood pressure.

Conclusively, cystatin $\mathrm{C}$ should be considered as an adjunct monitoring tool for renal function among hypertensive patients in particular those with uncontrolled B.P or associated obesity.

\section{References}

[1]. Adeloye D, Basquill C, Aderemi AV, Thompson JY, Obi FA. An estimate of the prevalence of hypertension in Nigeria: a systematic review and meta-analysis. J Hypertens. 2015; 33(2): 230-242.

[2]. Alebiosu OC, Ayodele OO, Abba A, Ina OA. Pattern of Chronic Renal failure in Nigeria. Afr Health Sci. $2006: 6$; 132-138.

[3]. Gooneratne IK, Ranaweera AK, Liganarachi NP, Gunawardane N, Lanerolle RD. Epidemiology of chronic kidney disease in a Sri Lankan population. Int J Diabetes Dev Cou. 2008; 28:60-64.

[4]. Gribbs CR, Beevers DG, Lip GYH. The management of hypertensive disease in black patients. QJM. 1999:4;187-192.

[5]. Nwankwo EA, Nwankwo B, Mubi B. Prevalence of impaired kidney function in hospitalized hypertensive patients in Maidiguri, Nigeria. Journal of internal Medicine. 2005; 6:1.

[6]. Delany MP, Price CP, Newman DJ, Lamb E. Kidney Function and Diseases, In: Tietz Textbook of Clinical Chemistry and Molecular Diagnostics. 1994. $4^{\text {th }}$ ed. Philadephia, Pa: Saunders; Burtis CA, Ashwood ER, eds. Pp. 818-26.

[7]. Van Acker BA, Koomen GC, Koopman MG, de wart DR, Arisz L. creatinine clearance during cimetidine administration for measurement of glomerular filtration rate. Lancet. 1992; 340: 1326-1329.

[8]. Tenstad O, Roald AB, Grubb A, Aucland K. Renal handling of radiolabelled human cystatin C in the rat. Scand J clin Lab Invest. 1996; 56:409-414.

[9]. Jacobsson B, Lignelid H, Bergerheim US. Transthyretin and Cystatin C are catabolised in proximal tubular epithelial cells and the proteins are not useful as markers for renal cell carcinomas. Histopathology. 1995; 26:559-564.

[10]. Ix JH. Utility of Cystatin C measurement - precision or secretion? Nephrol Dial Transplant. 2006; $21: 3614$.

[11]. Den Hollander JG. Wulkan RW, Mantel MJ, Berghout A. Is cystatin C a marker of glomerular filtration rate in thyroid dysfunction? Clin chem.2003; 49: 1558-1559. 
[12]. Font R, Prats M, Gutierrez C, Bardaji A, Lalana M, Marsillach J et al. Is there a relationship between cystatin C and inflammatory status, oxidative stress and other cardiovascular risk factors in non-diabetic patients with chronic kidney disease? Nephrologia. $2009 ; 29(3): 228-235$.

[13]. Esezobor CI, Soriyan OO, Iroha E. Serum Cystatin C level in Nigerian Children: Reference Intervals and Relationships with Demographic and Anthropometric Variables. WAJM. 2011; 30(3):188-192.

[14]. Ulasi II, Chiwuba KI. The Enormity of Chronic Kidney Disease in Nigeria:The Situation in a Teaching Hospital in South East Nigeria. J Trop Med: 2010:1-6.

[15]. Yusuf S, Vaz M, Pais P. tackling the challenge of cardiovascular disease burden in developing countries. Am Heart J. 2004;148:1-4

[16]. Samuel K. the case of visceral fat:argument for the defense. J Clin Invest. 2004:11:1530-1532.

[17]. Newman DJ. Cystatin C. Ann Clin Biochem. 2002:39; 89-104.

[18]. George LB, Eberhard R. Hypertension and Kidney disease: a marriage that should be prevented. World Kidney Day. 2009:12;1-5. 